\title{
PENGARUH CSR DAN KINERJA KEUANGAN TERHADAP NILAI PERUSAHAAN DENGAN KEPEMILIKAN MANAJERIAL SEBAGAI VARIABEL MODERATING
}

\author{
Audy Tri Saputra Meha ${ }^{1}$ \\ Jurusan Akuntansi, Sekolah Tinggi Ilmu Ekonomi Malangkucecwara \\ Sugeng Hariadi ${ }^{2}$ \\ Jurusan Akuntansi, Sekolah Tinggi Ilmu Ekonomi Malangkucecwara \\ E-mail : sugenghariadi@stie-mce.ac.id
}

\section{INFORMASI ARTIKEL}

Diterima Pertama

[15 01 2021]

Dinyatakan Diterima

[31 Maret 2021]

KATA KUNCI:

Corporate Social Responsibility, Kinerja Keuangan, Nilai Perusahaan, Kepemilikan Manajerial

KLASIFIKASI JEL:

M41

\section{ABSTRAK}

The purpose of this study is to examine the impact of corporate social responsibility and financial performance on firm value with managerial ownership as an intermediary variable. Corporate social responsibility and financial performance are used as independent variables. Meanwhile, firm value is used as the dependent variable. Managerial ownership is used as a moderating variable in this study. Manufacturing companies in the consumer goods industry sector listed on the Indonesia Stock Exchange in the 20172018 period are the population in this study. Purposive sampling method is a sampling method used in this study by producing 27 companies with 2 observations to produce a sample of 54. Multiple linear regression and moderation regression analysis are the analytical methods used in this study. This research shows that corporate social responsibility and financial performance have a positive and significant effect on firm value. Managerial ownership has a negative and significant effect on firm value. Then corporate social responsibility and financial performance with managerial ownership as the moderating variable have a positive and significant effect on firm value.

Tujuan penelitian ini adalah untuk menguji dampak corporate social responsibility dan kinerja keuangan pada nilai perusahaan dengan kepemilikan manajerial sebagai variabel perantara. Corporate social responsibility dan kinerja keuangan digunakan sebagai variable Independen. Sedangkan nilai perusahaan digunakan sebagai variable dependen. Kepemilikan manajerial yang digunakan sebagai variabel moderating dalam penelitian ini. Perusahaan manufaktur sektor industri barang konsumsi yang terdaftar di Bursa Efek Indonesia pada periode 2017-2018 merupakan populasi dalam penelitian ini. Metode purposive sampling merupakan metode penentuan sampel yang digunakan dalam penelitian ini dengan menghasilkan sebanyak 27 perusahaan dengan pengamatan selama 2 sehingga menghasilkan sampel sebanyak 54 . Regresi linier berganda dan analisis regresi moderasi merupakan metode analisis yang digunakan dalam penelitian ini. Dari penelitian ini menghasilkan bahwa corporate social responsibility dan kinerja keuangan berpengaruh positif dan signifikan terhadap nilai perusahaan. Kepemilikan manajerial berpengaruh negatif dan signifikan terhadap nilai perusahaan. Kemudian corporate social responsibility dan kinerja keuangan dengan kepemilikan manajerial sebagai variabel moderating berpengaruh positif dan signifikan terhadap nilai perusahaan. 


\section{PENDAHULUAN}

\subsection{Latar Belakang}

Perusahaan mempunyai tujuan utama yaitu memperoleh laba yang maksimal. Akan tetapi, hasil laba yang maksimal belum cukup secara jangka panjang untuk menjaga keberlanjutan hidup perusahaan. Oleh sebab itu penting bagi perusahaan untuk mempunyai tujuan lain yaitu dengan menaikkan nilai perusahaan. Nilai perusahaan sering dikaitkan dengan harga saham dan ini anggapan dari investor terhadap tingkat keberhasilan perusahaan.

Untuk dapat meningkatkan nilai perusahaan perlu diperhatikan beberapa faktor yang dapat mempengaruhinya. Faktor pertama yaitu CSR yang merupakan transparansi pengungkapan sosial atas informasi tentang dampak sosial dan lingkungan yang timbul akibat kegiatan perusahaan. Dengan melakukan kegiatan CSR, citra perusahaan semakin baik sehingga loyalitas konsumen tinggi. "Meningkatnya loyalitas konsumen dalam waktu yang lama akan membuat penjualan perusahaan semakin baik sehingga diharapkan profitabilitas perusahaan meningkat"(Sutopoyudo, 2009).

Faktor berikut yang mempengaruhi nilai perusahaan yaitu kinerja keuangan karena pengukuran tersebut digunakan sebagai dasar pengambilan keputusan dan memberikan informasi bagi pihak yang berkepentingan. "Dalam mengukur kinerja keuangan perlu dikaitkan antara perusahaan dengan pusat pertanggungjawaban" (Ermayanti, 2009). Perusahaan dapat menggunakan rasio untuk mengukur kinerja keuangan dengan rasio profitabilitas. Investor dapat menilai jika pertumbuhan Profitabilitas baik maka prospek perusahaan juga akan baik di masa mendatang.

Faktor lain adalah kepemilikan manajerial yang merupakan persentase saham yang dimiliki oleh pihak manajemen pada perusahaan. "Kepemilikan manajerial diperlukan agar dapat mensejajarkan perbedaan kepentingan antara manajemen dengan pemegang saham" (Sofyaningsih, 2011). Apabila kepemilikan manajerial semakin besar dalam perusahaan maka pihak manajemen akan semakin produktif dalam meningkatkan nilai perusahaan yang artinya mensejahterakan dirinya sendiri yang juga sebagai pemegang saham.

Beberapa penelitian membuktikan bahwa nilai perusahaan dapat dipengaruhi oleh CSR, kinerja keuangan, dan kepemilikan manajerial. Dalam penelitian Putri dan Budiyanto (2018) mengatakan bahwa "semakin banyak perusahaan mengungkapkan tanggung jawab sosialnya maka semakin besar nilai perusahaan". Selanjutnya menurut Heder dan Priyadi(2017) ROA merupakan proksi dari kinerja keuangan serta interaksi antara kepemilikan manajerial dan kinerja keuangan mempengaruhi nilai perusahaan. Dalam penelitian Ramadhani et al.(2017) membuktikan bahwa CSR dan kepemilikan manajerial berpengaruh signifikan terhadap nilai perusahaan. Putri dan Raharja (2013) menyatakan bahwa kepemilikan manajerial mampu memoderasi hubungan antara CSR terhadap nilai perusahaan.

Penelitian mengenai CSR, kinerja keuangan, nilai perusahaan, dan kepemilikan manajerial telah banyak dilakukan. Namun hasil yang berbeda didapat dari penelitian sebelumnya, maka peneliti berkeinginan untuk melakukan penelitian mengenai seberapa besar pengaruh CSR dan kinerja keuangan terhadap nilai perusahaan dengan kepemilikan manajerial sebagai variabel moderating. Sedangkan tujuan penelitian ini adalah untuk menguji pengaruh corporate social responsibility dan kinerja keuangan terhadap nilai perusahaan dengan variabel moderating kepemilikan manajerial pada perusahaan manufaktur sektor industri barang konsumsi yang terdaftar di Bursa Efek Indonesia.

\section{KERANGKA TEORI DAN PENGEMBANGAN HIPOTESIS}

\subsection{Teori Legitimasi}

Dalam teori legitimasi "perusahaan berusaha untuk menyesuaikan keadaan dengan peraturanperaturan yang berlaku di masyarakat sehingga dapat diterima di lingkungan eksternal karena dalam teori legitimasi menyatakan bahwa suatu organisasi hanya bisa bertahan jika masyarakat sekitar merasa bahwa organisasi beroperasi berdasarkan sistem nilai yang sepadan dengan sistem nilai yang dimiliki oleh masyarakat"(Sari, 2013).

\subsection{Teori Stakeholder}

Purwanto (2011) mengemukakan bahwa "stakeholder merupakan semua pihak yang keberadaannya sangat mempengaruhi dan dipengaruhi perusahaan, seperti : karyawan, masyarakat, perusahaan pesaing, dan pemerintah". Shidharta dalam Gantino (2016) menjelaskan bahwa "dalam teori stakeholder pelaksanaan CSR tidak hanya dihadapkan kepada pemilik atau kepada pemegang sahamnya saja, tetapi juga terhadap para stakeholder yang terkait dan terkena dampak dari keberadaan perusahaan".

\subsection{Teori Keagenan (Agency Theory)}

Teori keagenan berbicara mengenai pengendalian yang terpisah dan dampak dari pengelolaan perusahaan akan muncul konflik di antara agent dan principals. Menurut Sutedi(2012) tujuan dari pemisahan ini yaitu "agar pemilik perusahaan memperoleh keuntungan yang semaksimal mungkin dengan biaya yang seefisien mungkin karena dikelolanya perusahaan oleh tenaga-tenaga profesional".

\subsection{Nilai Perusahaan}

Menurut Noerirawan (2012), "nilai perusahaan merupakan kondisi yang telah dicapai oleh suatu perusahaan sebagai gambaran dari kepercayaan masyarakat terhadap perusahaan setelah melalui suatu proses kegiatan selama beberapa tahun, yaitu sejak perusahaan tersebut didirikan sampai saat ini". Samuel (2000) dalam Nurlela dan Islahuddin(2008), 
menjelaskan bahwa "enterprise value atau lebih dikenal dengan nilai perusahaan (firm value) merupakan konsep penting bagi investor, karena merupakan indikator bagi pasar untuk menilai perusahaan secara keseluruhan".

\subsection{Corporate Social Responsibility}

Heri (2013) menyatakan bahwa "corporate social responsibility adalah komitmen perusahaan dalam memberikan kontribusi jangka panjang terhadap suatu issue tertentu di masyarakat atau lingkungan untuk dapat menciptakan lingkungan yang lebih baik". "CSR dalam pengungkapannya harus berdasarkan pemahaman 3P (profit, people, planet) yang artinya bahwa bisnis tidak hanya mencari laba (profit), tetapi juga menyejahterakan orang (people), dan menjamin keberlanjutan hidup planet ini"(Anggitasari, 2012).

\subsection{Kinerja Keuangan}

Menurut Fahmi (2013) "kinerja keuangan adalah suatu analisis yang dilakukan untuk melihat sejauh mana suatu perusahaan telah melaksanakan dengan aturan-aturan pelaksanaan keuangan secara baik dan benar". Beberapa alat pengukuran untuk kinerja keuangan : 1) Rasio Aktivitas, 2) Rasio Likuiditas, 3) Rasio Profitabilitas, 4) Rasio Solvabilitas, 5) Rasio Pasar

\subsection{Kepemilikan Manajerial}

Menurut Downes dan Goddman dalam Sukirni(2012), bahwa "kepemilikan manajerial adalah para pemegang saham yang juga berarti dalam hal ini sebagai pemilik dalam perusahaan dan manajer secara aktif ikut dalam pengambilan keputusan pada suatu perusahaan yang bersangkutan". Peran penting dipegang manajemen karena menjalankan fungsi perencanaan, pengorganisasian, pengarahan, pengawasan dan pengambilan keputusan.

\subsection{Pengembangan Hipotesis.}

$\mathbf{H}_{\mathbf{1}}$ : Corporate Social Responsibility berpengaruh positif terhadap Nilai Perusahaan.

$\mathbf{H}_{\mathbf{2}}$ : Kinerja Keuangan berpengaruh positif terhadap Nilai Perusahaan.

$\mathbf{H}_{\mathbf{3}}$ : Corporate Social Responsibility berpengaruh positif terhadap Nilai Perusahaan dengan Kepemilikan Manajerial sebagai Variabel Moderating.

$\mathbf{H}_{\mathbf{4}}$ : Kinerja Keuangan berpengaruh positif terhadap nilai perusahaan dengan Kepemilikan Manajerial sebagai Variabel Moderating.

\section{METODE PENELITIAN}

Jenis penelitian ini adalah penelitian kuantitatif kausalitas. Perusahaan manufaktur sektor industri barang konsumsi yang dijadikan populasi dalam penelitian ini yaitu sebanyak 58 perusahaan yang terdaftar di Bursa Efek Indonesia tahun 2017-2018. Dari populasi tersebut diperoleh 27 perusahaan yang digunakan sebagai sampel selama periode 2017-2018. Purposive sampling dijadikan teknik pengambilan sampel dalam penelitian ini dengan sumber data sekunder dari website Bursa Efek Indonesia.
Variabel independen pertama (X1) dalam penelitian ini adalah corporate social responsibiity (CSR). Variabel independen kedua (X2) adalah kinerja keuangan dengan menggunakan rasio profitabilitas yang diproksikan dengan ROA. Variabel dependen (Y) adalah nilai perusahaan. Variabel moderating (X3) adalah kepemilikan manajerial.

Dalam penelitian menggunakan metode analisis statistik deskriptif, uji asumsi klasik yang meliputi uji normalitas, uji multikolinieritas, uji autokorelasi, dan uji heteroskedastisitas. Metode statistik untuk menguji hipotesis adalah regresi linier berganda dengan Moderated Regression Analysis (MRA). Dalam melakukan uji hipotesis yaitu dengan uji koefisien korelasi dan determinasi, dan uji statistik $F$, serta uji parsial (uji statistik t).

\section{Persamaan Regresi 1 :}

$Y=\alpha+\beta_{1} X_{1}+\beta_{2} X_{2}+e$

Keterangan :

$\mathrm{Y}$ : Nilai Perusahaan

$\alpha$ : Konstanta

$\beta_{1}-\beta_{2}$ : Koefisien Regresi

$\mathrm{X}_{1}$ : Corporate Social Responsibility (CSR)

$\mathrm{X}_{2}$ : Kinerja Keuangan (ROA)

e : error term, yaitu tingkat kesalahan penduga dalam penelitian

Persamaan Regresi 2 (MRA) :

$Y=\alpha+\beta_{1} X_{1}+\beta_{2} X_{2}+\beta_{3} X_{3}+\beta_{4} X_{1} X_{3}+\beta_{5} X_{2} X_{3}+e$

Keterangan :

$Y$ : Nilai Perusahaan

$\alpha$ : Konstanta

$\beta_{1}-\beta_{5}$ : Koefisien Regresi

$\mathrm{X}_{1}$ : Corporate Social Responsibility (CSR)

$\mathrm{X}_{2}$ : Kinerja Keuangan (ROA)

$X_{3}$ : Kepemilikan Manajerial

$\mathrm{X}_{1} \mathrm{X}_{3}$ : Interaksi antara CSR dengan Kepemilikan Manajerial

$\mathrm{X}_{2} \mathrm{X}_{3}$ : Interaksi antara Kinerja Keuangan dengan Kepemilikan Manajerial

e : error term, yaitu tingkat kesalahan penduga dalam penelitian

\section{HASIL PENELITIAN}

\subsection{Statistik Deskriptif}

Dengan cara memberikan gambaran dari pengamatan variable-variabel dalam penelitian ini yaitu corporate social responsibility, kinerja keuangan (ROA), kepemilikan manajerial, dan nilai perusahaan.

Tabel 1. Hasil Analisis Statistik Deskriptif

\begin{tabular}{lccccc}
\hline & N & Min & Max & Mean & $\begin{array}{c}\text { Std. } \\
\text { Deviation }\end{array}$ \\
\hline CSR & 54 & 0,025 & 0,279 & 0,154 & 0,065 \\
\hline ROA & 54 & 0,004 & 0,527 & 0,116 & 0,115 \\
\hline $\begin{array}{l}\text { Kepemilikan } \\
\text { Manajerial }\end{array}$ & 54 & 0,000 & 0,380 & 0,041 & 0,103 \\
\hline $\begin{array}{l}\text { Nilai } \\
\text { Perusahaan }\end{array}$ & 54 & 0,321 & 23,286 & 3,342 & 4,504 \\
\hline Valid N & & & & &
\end{tabular}

Berdasarkan tabel di atas menunjukkan hasil statistik yang dilakukan dengan jumlah sampel 
sebanyak 54 perusahaan. Hasil tersebut menunjukkan bahwa variabel CSR (X1) memiliki nilai minimum adalah 0,025 , nilai maximum adalah 0,279 , nilai rata-rata CSR adalah 0,154, dan standar deviasinya adalah 0,065. Variabel kinerja keuangan sebagai proksinya adalah ROA (X2) memiliki nilai minimum adalah 0,004, nilai maximum adalah 0,527 , nilai rata-rata ROA adalah 0,116 , dan standar deviasinya adalah 0,115. Variabel kepemilikan manajerial (X3) dengan nilai minimum adalah 0,000 , nilai maximum adalah 0,380 , nilai ratarata kepemilikan manajerial adalah 0,041, dan standar deviasinya adalah 0,103 . Variabel nilai perusahaan $(Y)$ dengan nilai minimum adalah 0,321 , nilai maximum adalah 23,286, nilai rata-rata nilai perusahaan adalah 3,342, dan standar deviasinya adalah 4,504.

\subsection{Uji Asumsi Klasik}

\subsubsection{Uji Normalitas}

Kolmogorov-Smirnov Test digunakan dalam uji Normalitas dalam penelitian ini. Hasil uji statistik Kolmogorov-Smirnov menunjukkan hasil 0,775 dan dinyatakan bahwa terdistribusi normal jika angka tersebut lebih besar dari nilai signifikan yang ditetapkan yaitu 0,05 .

\subsubsection{Uji Multikolinieritas}

Hasil uji multikolinieritas untuk variabel CSR mempunyai toleransi nilai sebesar 0,912 dan nilai VIF sebesar 1,096, untuk variabel kinerja keuangan (ROA) mempunyai toleransi nilai sebesar 0,959 dan nilai VIF sebesar 1,042, dan variabel kepemilikan manajerial memiliki toleransi nilai sebesar 0,937 dan nilai VIF sebesar 1,067. Hasil tersebut menunjukkan bahwa dalam penelitian ini, variabel-variabel tidak saling berhubungan karena memiliki nilai Tolerance< 0,10 serta nilai VIF < 10. Maka dapat disimpulkan bahwa tidak ditemukan indikasi adanya multikolinieritas.

\subsubsection{Uji Autokorelasi}

Dalam penelitian ini dengan uji Durbin Watson dilakukan untuk menguji autokorelasi dalam penelitian ini. Berdasarkan hasil uji autokorelasi dengan DurbinWatson menunjukkan nilai sebesar 1,925. Uji DurbinWatson dilihat dengan ketentuan $\mathrm{du}<\mathrm{d}<4-\mathrm{du}$, sehingga diperoleh hasil 1,680 $<1,925<2,320$. Hasil tersebut menunjukkan bahwa jika D-W berada di antara nilai du dan 4 - du maka model regresi dinyatakan tidak mengalami autokorelasi.

\subsubsection{Uji Heteroskedastisitas}

Berdasarkan hasil uji heteroskedastisitas dengan scatterplot untuk melihat titik-titik menyebar secara acak dan tersebar baik di atas maupun di bawah angka 0 pada sumbu Y. Hal ini dinyatakan bahwa tidak terjadi heteroskedastisitas pada model regresi ini.

\subsection{Uji Hipotesis}

\subsubsection{Uji Koefisien dan Determinasi}

Tabel 2. Hasil Uji Koefisien Korelasi dan Determinasi Persamaan 1

\begin{tabular}{lllll} 
Model & $\mathrm{R}$ & $\mathrm{R}$ & Adjusted & Std. Error of \\
\hline
\end{tabular}

\begin{tabular}{|c|c|c|c|c|}
\hline & & Square & R Square & the Estimate \\
\hline 1 & 0,884 & 0,782 & 0,774 & 2.1 \\
\hline
\end{tabular}

kekuatan hubungan $(R)$ sebesar $0,884(88,4 \%)$. Hal ini menunjukkan bahwa hubungan dari model regresi ini adalah sangat kuat. Nilai koefisien determinasi $\left(R^{2}\right)$ adalah sebesar 0,782 (78,2\%), artinya bahwa besarnya kontribusi variabel dalam persamaan regresi ini terhadap Nilai Perusahaan adalah sebesar $78,2 \%$ dan sisanya $21,8 \%(100 \%-78,2 \%=21,8 \%)$ berasal dari faktor-faktor lain atau variable lain di luar persamaan pertama.

Tabel 3. Hasil Uji Koefisien Korelasi dan Determinasi Persamaan 2

\begin{tabular}{|c|c|c|c|c|}
\hline Model & $\mathrm{R}$ & $\begin{array}{c}\mathrm{R} \\
\text { Square }\end{array}$ & $\begin{array}{l}\text { Adjusted } \\
\text { R Square }\end{array}$ & $\begin{array}{l}\text { Std. Error of } \\
\text { the Estimate }\end{array}$ \\
\hline 1 & 0,951 & 0,904 & 0,895 & 1,462911179 \\
\hline
\end{tabular}

kekuatan hubungan (R) sebesar 0,951 $(95,1 \%)$. Hal ini menunjukkan bahwa hubungan dari model regresi ini adalah sangat kuat. Nilai koefisien determinasi $\left(R^{2}\right)$ adalah sebesar 0,904 (90,4\%), artinya bahwa besarnya kontribusi variabel dalam persamaan regresi ini terhadap Nilai Perusahaan adalah sebesar 90,4\% dan sisanya $9,6 \%(100 \%-90,4 \%=9,6 \%)$ berasal dari faktorfaktor lain atau variabel lain di luar persamaan kedua.

\subsubsection{Uji Statistik $F$}

Tabel 4. Hasil Uji Statistik F Persamaan 1

\begin{tabular}{llrrrrc}
\hline Model & & $\begin{array}{c}\text { Sum of } \\
\text { Squares }\end{array}$ & df & MeanSquare & $F$ & Sig. \\
\hline 1 & Regression & 841,251 & 2 & 420,625 & 91,637 & 0,000 \\
\hline & Residual & 234,096 & 51 & 4,590 & & \\
\hline & Total & 1075,347 & 53 & & & \\
\hline
\end{tabular}

Berdasarkan tabel di atas nilai $F_{\text {hitung }}$ sebesar 91,637 > $F_{\text {tabel }}$ sebesar 3,18 dengan nilai probabilitas signifikan sebesar $0,000<0,05$. Hal ini menunjukkan bahwa variabel dalam kesamaan regresi ini secara bersama-sama mempunyai pengaruh signifikan terhadap Nilai Perusahaan. Sehingga model regresi yang digunakan adalah model yang fit menjadi kesimpulan dalam persamaan ini.

Tabel 5. Hasil Uji Statistik F Persamaan 2

\begin{tabular}{lllrccc}
\hline Model & & $\begin{array}{c}\text { Sum of } \\
\text { Squares }\end{array}$ & df & Square & $F$ & Sig. \\
\hline 1 & Regression & 972,621 & 5 & 194,524 & 90,895 & 0,000 \\
\hline & Residual & 102,725 & 48 & 2,140 & & \\
\hline & Total & 1075,347 & 53 & & & \\
\hline
\end{tabular}

Berdasarkan tabel di atas nilai $F_{\text {hitung }}$ sebesar $90,895>F_{\text {tabel }}$ sebesar 2,40 dan nilai probabilitas signifikan sebesar $0,000<0,05$. Hal ini menunjukkan bahwa variabel dalam persamaan regresi ini secara bersama-sama berpengaruh signifikan terhadap Nilai Perusahaan. Sehingga disimpulkan model yang fit dapat digunakan dalam model regresi ini.

\subsubsection{Uji Parsial (Uji Statistik t)}

Tabel 6. Hasil Uji Statistik t Persamaan 1

\begin{tabular}{llllll}
\hline & \multicolumn{2}{l}{$\begin{array}{l}\text { Unstandardize } \\
\text { d Coefficients }\end{array}$} & $\begin{array}{c}\text { Standardized } \\
\text { Coefficients }\end{array}$ & & \\
\cline { 2 - 4 } Model & B & Std. & Beta & t & Sig. \\
\hline
\end{tabular}




\begin{tabular}{rrrrrrr}
\hline & & & Error & & & \\
\hline 1 & (Constant) & $-1,935$ & 0,768 & & $-2,521$ & 0,015 \\
\hline & CSR & 9,659 & 4,729 & 0,138 & 2,043 & 0,046 \\
\hline & ROA & 32,835 & 2,658 & 0,837 & 12,355 & 0,000 \\
\hline
\end{tabular}

Berdasarkan hasil uji statistik t dari persamaan pertama di atas menunjukkan bahwa :

Nilai $\mathrm{T}_{\text {hitung }} \operatorname{CSR}\left(\mathrm{X}_{1}\right)$ adalah sebesar 2,043 > nilai $T_{\text {tabel }} 2,00758$ serta nilai probabilitas signifikan sebesar $0,046<0,05$. Karena nilai $\mathrm{T}_{\text {hitung }} \operatorname{CSR}\left(\mathrm{X}_{1}\right) 2,043>$ nilai $\mathrm{T}_{\text {tabel }} 2,00758$ dan nilai signifikan $0,046<0,05$, maka $\mathrm{H}_{0}$ ditolak dan $\mathrm{H}_{1}$ diterima. Hal ini menunjukkan bahwa secara positif dan signifikan terhadap Nilai Perusahaan dipengaruhi oleh CSR.

Nilai $T_{\text {hitung }}$ dengan menggunakan ROA $\left(X_{2}\right)$ sebagai proksi dari kinerja keuangan yaitu sebesar $12,355>$ nilai $T_{\text {tabel }} 2,00758$ dengan nilai probabilitas signifikan sebesar $0,000<0,05$. Karena nilai $T_{\text {hitung }}$ ROA $\left(\mathrm{X}_{2}\right)$ 12,355 > nilai $\mathrm{T}_{\text {tabel }} 2,00758$ dan nilai signifikan $0,000<0,05$, maka $\mathrm{H}_{0}$ ditolak dan $\mathrm{H}_{2}$ diterima. Hal ini menunjukkan ROA $\left(\mathrm{X}_{2}\right)$ sebagai proksi dari kinerja keuangan berpengaruh secara signifikan dan positif terhadap Nilai Perusahaan.

Tabel 7. Hasil Uji Statistik t Persamaan 2

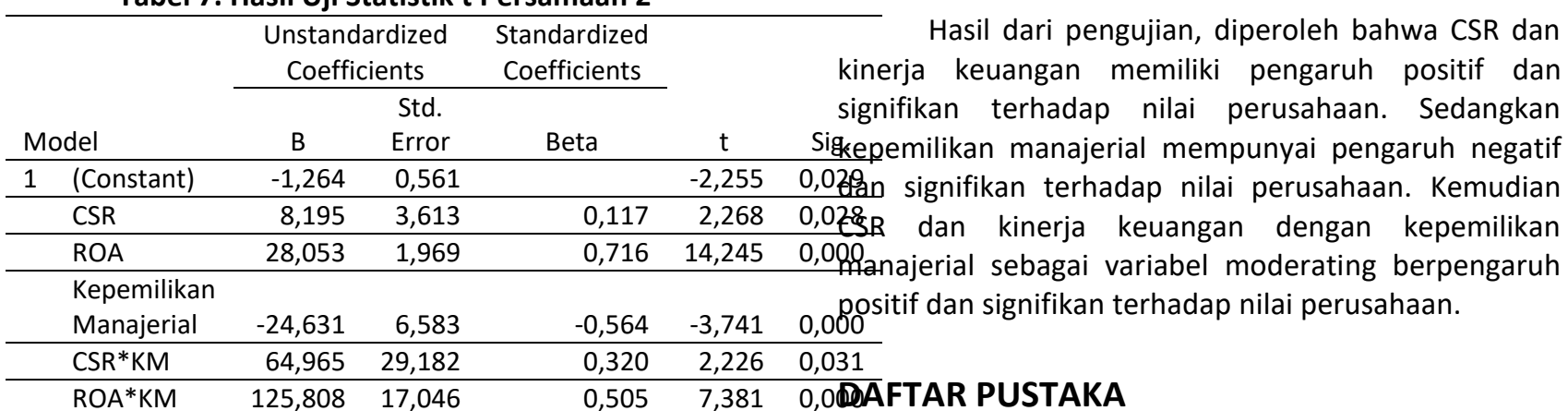

Berdasarkan hasil uji statistik t dari persamaan kedua menunjukkan bahwa :

Nilai $T_{\text {hitung }} \operatorname{CSR}\left(\mathrm{X}_{1}\right)$ adalah sebesar 2,268 > nilai $T_{\text {tabel }} 2,01063$ serta nilai probabilitas signifikan sebesar $0,028<0,05$. Karena nilai $\mathrm{T}_{\text {hitung }} \operatorname{CSR}\left(\mathrm{X}_{1}\right) 2,268>$ nilai $\mathrm{T}_{\text {tabel }} 2,01063$ dan nilai signifikan $0,028<0,05$, maka $\mathrm{H}_{0}$ ditolak dan $\mathrm{H}_{1}$ diterima. Hal ini membuktikan bahwa CSR secara positif dan signifikan mempengaruhi terhadap Nilai Perusahaan.

Nilai $T_{\text {hitung }} \mathrm{ROA}\left(\mathrm{X}_{2}\right)$ sebagai proksi dari Kinerja Keuangan adalah sebesar 14,245 $>$ nilai $T_{\text {tabel }} 2,01063$ serta nilai probabilitas signifikan sebesar 0,000 0,05. Karena nilai $T_{\text {hitung }}$ Kinerja Keuangan yang diproksikan dengan ROA $\left(X_{2}\right) 14,245>$ nilai $T_{\text {tabel }} 2,01063$ dan nilai signifikan $0,000<0,05$, maka $\mathrm{H}_{0}$ ditolak dan $\mathrm{H}_{2}$ diterima. Hal ini menunjukkan bahwa ROA sebagai proksi dari Kinerja Keuangan berpengaruh signifikan dan positif terhadap Nilai Perusahaan.

Nilai $T_{\text {hitung }}$ Kepemilikan Manajerial $\left(X_{3}\right)$ adalah sebesar $-3,741<$ nilai $T_{\text {tabel }} 2,01063$ serta nilai probabilitas signifikan sebesar $0,000<0,05$. Karena nilai $\mathrm{T}_{\text {hitung }}$ Kepemilikan Manajerial $\left(\mathrm{X}_{3}\right)-3,741<$ nilai $\mathrm{T}_{\text {tabel }}$ 2,01063 dan nilai signifikan $0,000<0,05$, maka $\mathrm{H}_{0}$ diterima dan $\mathrm{H}_{3}$ ditolak. Hal ini menunjukkan bahwa Kepemilikan Manajerial signifikan mempengaruh secara negatif terhadap Nilai Perusahaan.

Nilai $T_{\text {hitung }}$ interaksi antara CSR dengan Kepemilikan Manajerial $\left(X_{1} X_{3}\right)$ adalah sebesar 2,226 > nilai $\mathrm{T}_{\text {tabel }}$ 2,01063 serta nilai probabilitas signifikan sebesar $0,031<0,05$. Karena nilai $T_{\text {hitung }}$ interaksi antara CSR dengan Kepemilikan Manajerial $\left(X_{1} X_{3}\right) 2,226>$ nilai $\mathrm{T}_{\text {tabel }} 2,01063$ dan nilai signifikan 0,031 $<0,05$, maka $\mathrm{H}_{0}$ ditolak dan $\mathrm{H}_{4}$ diterima. Sehingga membuktikan bahwa interaksi antara CSR dengan Kepemilikan Manajerial berpengaruh signifikan dan positif terhadap Nilai Perusahaan.

Nilai $\mathrm{T}_{\text {hitung }}$ interaksi antara Kinerja Keuangan yang diproksikan menggunakan ROA dengan Kepemilikan Manajerial $\left(\mathrm{X}_{2} \mathrm{X}_{3}\right)$ adalah sebesar 7,381 > nilai $T_{\text {tabel }}$ 2,01063 serta signifikan nilai dari probabilitas sebesar $0,000<0,05$. Karena nilai $T_{\text {hitung }}$ interaksi antara Kinerja Keuangan yang diproksikan menggunakan ROA dengan Kepemilikan Manajerial $\left(X_{2} X_{3}\right) 7,381>$ nilai $T_{\text {tabel }}$ 2,01063 serta signifikan nilainya sebesar $0,000<0,05$, maka $\mathrm{H}_{0}$ ditolak dan $\mathrm{H}_{5}$ diterima. Sehingga membuktikan bahwa interaksi antara ROA sebagai proksi dari Kinerja Keuangan dengan Kepemilikan Manajerial berpengaruh signifikan dan positif terhadap Nilai Perusahaan.

\section{KESIMPULAN DAN SARAN}

kinerja keuangan memiliki pengaruh positif dan signifikan terhadap nilai perusahaan. Sedangkan Sigkepemilikan manajerial mempunyai pengaruh negatif

Anggitasari, N. (2012). Pengaruh Kinerja Keuangan Terhadap Nilai Perusahaan Dengan Pengungkapan CSR dan Struktur Good Corporate Governance Sebagai Variabel Pemoderasi. Skripsi. Universitas Diponegoro. Semarang.

Ermayanti, D. (2009). Kinerja Keuangan Perusahaan. www.wordpress.com

Fahmi, I. (2013). Analisis Laporan Keuangan. Bandung: Alfabeta.

Gantino, R. (2016). Pengaruh Corporate Social Responsibility Terhadap Kinerja Keuangan Perusahaan Manufaktur yang Terdaftar di Bursa Efek Indonesia periode 2008-2014. Jurnal Dinamika Akuntansi Dan Bisnis. https://doi.org/10.24815/jdab.v3i2.5384

Heder, \& Priyadi, M. P. (2017). Pengaruh Kinerja Keuangan terhadap Nilai Perusahaan dengan Good Corporate Governance sebagai Variabel Pemoderasi. Jurnal IImu Dan Riset Akuntansi, 6, 1-25.

Heri. (2013). Akuntansi dan Rahasia Dibaliknya untuk Para Manajer Non Akuntansi. Jakarta: PT Bumi Aksara.

Noerirawan, M. R. (2012). Pengaruh Faktor Internal dan Eksternal Perusahaan terhadap Nilai Perusahaan. Jurnal Akuntansi, 1(2).

Nurlela, R., \& Islahuddin. (2008). Pengaruh Corporate Social Responsibility terhadap Nilai Perusahaan 
dengan Prosentase Kepemilikan Manajemen sebagai Variabel Moderating (Studi Empiris pada Perusahaan yang Terdaftar di Bursa Efek Jakarta). Simposium Nasional Akuntansi (SNA) Ke XI.

Purwanto, A. (2011). Pengaruh Tipe Industri, Ukuran Perusahaan, Profitabilitas, Terhadap Corporate Social Responsiblity. Universitas Diponegoro.

Putri, H. C. M. P., \& Raharja, S. (2013). Pengaruh Corporate Social Responsibility terhadap Nilai Perusahaan dengan Kepemilikan Manajerial sebagai Variabel Moderating. Diponegoro Journal Of Accounting, 2, 1-15.

Putri, Z. B., \& Budiyanto. (2018). Pengaruh Corporate Social Responsibility Terhadap Nilai Perusahaan Dengan Kepemilikan Manajerial Sebagai Variabel Moderating. Jurnal IImu Dan Riset Manajemen, 361-375.

Ramadhani, A. R., Purnamawati, I. G. A., \& Sujana, E. (2017). Pengaruh Corporate Social Responsibility Dan Kepemilikan Manajerial Terhadap Nilai Perusahaan Dengan Profitabilitas Sebagai Variabel Moderating. E-Journal S1 Ak Universitas Pendidikan Ganesha, 7(1).

Sari. (2013). Pengaruh Pengungkapan CSR terhadap Nilai Perusahaan dengan Profitabilitas sebagai Variabel Pemoderasi. E-Jurnal Akuntansi Universitas Udayana, 5(3).

Sofyaningsih, S. (2011). Struktur Kepemilikan, Kebijakan Deviden, Kebijakan Perusahaan, Ownership Structure, Deviden Policy and Debt Policy. Dinamika Keuangan Dan Perbankan, 3(1).

Sukirni, D. (2012). Kepemilikan Manajerial, Kepemilikan Institusional, Kebijakan Dividen Dan Kebijakan Hutang. Accounting Analysis Journal.

Sutedi, A. (2012). Good Corporate Governance. Jakarta: Sinar Grafika.

Sutopoyudo. (2009). Pengaruh Penerapan Corporate Social Responsibility (CSR) terhadap Profitabilitas Perusahaan. http://www.wordpress.com 